\title{
Oversættelse af komposita i fagsproglige tekster (Eng-da/da-eng)
}

\section{Indledning}

De fleste simpleksord på engelsk og dansk kan sættes sammen med et andet simpleksord, så der fremkommer komposita. Under sprogudøvelsen kan der løbende genereres nye komposita uden at kommunikationen belastes, fordi komposita ofte er umiddelbart forståelige i situationen.

En overordentlig hyppig dannelse er eksempelvis sammensætninger af stednavn og appellativ (typen Kalundborgegnen, Århus-mфdet). Flertallet af sådanne dannelser forbliver $a d$ hoc dannelser, men undertiden etableres de i sprogbrugen i en sådan grad, at de må siges at være leksikaliserede 1 . Ord som worcestersovs, jerseyko og flere sammensætninger med wienersom første element (wienerbarn, wienerbr $\phi d$, wienervals $\mathrm{m}$. fl.) er således leksikaliserede i dansk almensprog, og i forskellige faglige sammenhæng anvendes sammensætninger som københavnerkredsen eller London-sofa med fagligt veletableret, ikke-situationsafhængigt betydningsindhold.

Når en sammensætnings betydningsindhold etableres, har det som konsekvens, at indholdet oftest ikke mere lader sig inferere ud fra situationen og kendskab til betydningen af elementerne i i sammensætningen alene. Sammensætningens etablerede betydning indebærer typisk en begrænsning i forhold til sammensætningens betydningspotentiale på baggrund af de indgående ords egenbetydninger. For den uindviede kan københavnerkredsen eller en London-sofa være mange ting, men for den indviede er det noget ganske bestemt. Hvad den selekterede betydning er, er man nødt til at vide.

Det forklarer, hvorfor brugere uden særlig faglig og fagsproglig viden ikke er i stand til at generere de relevante leksikaliserede fagsproglige komposita på modersmålet ved såkaldt komposition. Komposition er

\footnotetext{
1 Som det fremgår, afgøres et ords leksikalisering ikke af, om det faktisk er registreret i en ordbog, men af hvor etableret et ord er i sprogbrugen. For fagsproglige leksemers vedkommende er det afgørende spørgsmål, hvor etableret et ord er i sprogbrugen blandt dem, der tegner det pågældende fag.
} 
dannelse af sammensætninger ud fra sprogregler. Tilsvarende er dekomposition opløsning af sammensætninger i elementer, ligeledes ud fra regler. Når komposition og dekomposition begge er utilstrækkelige til dannelse, hhv. tydning, af leksikaliserede komposita, er årsagen, at de komposita der er leksikaliseret i et fagsprog (hhv. de betydninger de har), er selekteret blandt mange mulige sammensætninger, hver med et meget stort betydningspotentiale. Selv om et kompositum opløses korrekt i elementer, har man ikke dermed forstået dets etablerede betydning. Faktisk virker leksikaliserede komposita ofte ret tilfældigt, eller ligefrem ulogisk konstruerede.

Denne artikels påstand er, at ligesom det er nødvendigt at skaffe sig viden om de leksikaliserede fagsproglige kompositas betydning på modermålets fagsprog, således er det også nødvendigt at erhverve sig viden om oversættelsesækvivalenterne på målsproget, for at kunne oversætte disse komposita. (De)komposition er heller ikke anvendelig som oversættelsesstrategi, for selv om oversætteren (de)komponerer i overensstemmelse med reglerne, er det kun i begrænset omfang sandsynligt, at en sammensætning på målsproget af ækvivalente elementer vil være betydningsækvivalent med det kildesproglige kompositum. Der er endog kun begrænset sandsynlighed for, at hvad der udtrykkes med et sammensat ord på det ene sprog også udtrykkes sammensat på det andet.

Når det gælder ikke-leksikaliserede komposita (ad hoc dannelser) er situationen den, at indfødte sprogbrugere med de relevante faglige forudsætninger, og med de sædvanligvis foreliggende kontekstuelle tolkningsbegrænsninger, normalt er i stand til at komponere dem forståeligt og at forstå andres. Forklaringen herpå er, at sådanne komposita dannes ud fra relativt få og meget produktive regler, så tolkningsmulighederne er begrænsede.

Men den omstændighed, at ikke-leksikaliserede komposita produceres og tydes på ét sprog, betyder ikke nødvendigvis, at man som oversættelsesstrategi kan vælge at kalkere disse dannelser element for element. For det første er det muligt, at kildesprogets kompositumstype ikke forekommer på målsproget. For det andet er det muligt, at der foreligger flere alternative kompositeringsmuligheder, hvoraf kun én anvendes af indfødte fageksperter. Endelig er der det forhold, at det ikke a priori kan antages, at der vil være isomorfi imellem fagbegreber på de to sprog. Den omstændighed, at vi på dansk udtrykker et givet fagsprogligt begreb med et ikke-leksikaliseret kompositum dannet efter en af de hyperproduktive regler tillader os ikke at antage, at det samme er tilfældet på engelsk. 
Konsekvensen af disse forhold er, at uanset at vi kan påvise ligheder både med hensyn til, hvordan komposita dannes, og hvor produktive bestemte kompositeringstyper er, og uanset at vi kan finde mange eksempler på parallelt dannede betydningsækvivalente former, kan disse iagttagelser ikke generaliseres, så det er muligt ud fra analysen af et dansk eller engelsk kompositum at forudsige, hvordan det kan eller skal oversættes til det andet sprog.

Denne situation rejser flere praktiske spørgsmål, nemlig for det første spørgsmålet om omfanget af to-sprogede ordbøgers behandling af komposita, for det andet spørgsmålet om hvilke relevante informationssøgningsmuligheder, der kan peges på i de tilfælde, hvor ordbogen enten er mangelfuld eller ikke er til rådighed, og endelig spørgsmålet om hvilke oversættelsesstrategier, der kan anbefales i de tilfælde, hvor en oversætter ikke har, og hvor det ikke er muligt at opnå, sikker viden. I det følfende søges især det første af disse spørgsmål belyst.

\section{Grundlagsdiskussion}

Nogle vil måske mene, at det er nødvendigt allerførst at spørge, om det overhovedet er meningsfuldt at tale om, hvordan man oversætter komposita. Det herskende oversættelsesteoretiske synspunkt er vel nu, at oversættelse handler om formidling af hele budskaber, hele tekster. At der ved oversættelse naturligvis i en vis forstand er tale om en lingvistisk transfer, men at det afgørende er den såkaldt 'kulturelle' transfer ${ }^{2}$ samt hvor 'adækvat' teksten er i forhold til målsprogets tekstnormer ${ }^{3}$.

I nærværende artikel betegner ordene oversatte og oversattelse ikke kun idealaktiviteten, den optimale gengivelse af hele budskaber. Oversættelse forstås her som et kompleks af kognitive, sproglige og tekstlige operationer, hvori indgår det at finde ækvivalenter til betegnelser for fænomener, som kildesprogets brugere normalt oplever som relativt veldefinerede virkelighedsudsnit. I de senere år er der sket en specialisering i oversættelsesteori og (tosprogs)leksikografi, der har ført til, at det ofte overses, at oversættelsesordbogen (bortset fra maskinoversættelsessystemerne) kommer en implementeret teori om oversættelse mellem et

\footnotetext{
2 Se f. eks. Justa Holz-Mänttäri (1984) Translatorisches Handeln. Theorie und Methode Helsinki: Suomalainen Tiedeakatemia og Mary Snell-Hornby (1988) Translation Studies. An Integrated Approach Amsterdam: J. Benjamins.

3 Jf. den såkaldte Skopos-teori udviklet i K. Reiss og H. Vermeer (1984) Grundlegung einer allgemeinen Translationstheorie Tübingen: Niemeyer.
} 
givet sprogpar nærmere end de fleste såkaldte oversættelsesteorier. Oversættelsesordbøgernes oversættelsesteori kan formuleres meget enkelt: en manifestation af et lemma ækvivalerer én (evt. flere) af de oversættelsesforslag, artiklen om dette lemma indeholder. Det er en meget grov og helt utilstrækkelig teori, men den peger konkret på det, der er kernen i al oversættelse, nemlig den sproglige transfer, en kerne som oversættelsesteoretikere bør holde sig klart for øje.

Oversættelse kan ikke beskrives som en ord-for-ord- og heller ikke som en kompositum-for-kompositum-aktivitet, men på den anden side heller ikke uden reference til sådanne detaljerede og konkrete overvejelser over, hvilke ord, og altså hvilke komposita, der svarer til hvilke på det andet sprog.

\section{Fagsproglige komposita på dansk og engelsk}

Når talen er om komposita, ligger det allerede i ordet, at komposita er sammensatte størrelser. Det er ord der er sammensat af ord.

Der er et ord guld og et ord vagt. Begge disse ord optræder med en veldefineret og selvstændig grammatisk funktion i almindeligt forekommende danske sætninger, og de optræder begge med fleksionsendelser: guld-et-s, vagt-en osv. Der kan dannes deriverede former ud fra dem begge, som gyld-en, vagt-ig og andre, som igen optræder med fleksionsendelser: gyldn-e, vagtig-e osv. Og, som det ses, kan der også forekomme vokalomlyd og vokalelision i forbindelse med dannelsen af afledte former. Herudover optræder de to ord også som ortografisk enhed, som kompositum, i formen guldvagt.

I et kompositum er rækkefølgen mellem leddene fast. Hvis der ændres på elementrækkefølgen bliver resultatet enten, at der fremkommer en uanvendelig kombination (*vagtguld), eller at der dannes et kompositum med en helt ny betydning (fx. brudsten vs. stenbrud, boligejer vs. ejerbolig), evt. med forskellig ordklasse (fx. fuldmagt vs. magtfuld), altså et nyt og andet ord.

Endvidere optræder første element altid i samme bøjningsform af ordet, hvorimod andet element, som er bestemmende for kompositummets genus/numerus/kasusforhold, kan tilføjes bøjningsendelser til markering af disse forhold ${ }^{4}$.

4 Engelske undtagelser er nogle sammensætninger af substantiv + præposition (mothers- in-law), substantiv + adverbium (passers-by, men stowaways) og substantiv + adjektiv (postmasters gene- 
Bortset fra en iøjnefaldende forskel i ortografisk konvention mellem dansk og engelsk (og enkelte undtagelser) gælder det foregående såvel om danske som om engelske komposita. Hvor samskrivning stadig er normen ved danske kompositumsformer (med eller uden bindestreg), er særskrivning normen i engelsk (med mulighed både for bindestreg og samskrivning).

Endnu en iøjnefaldende forskel består i, at dansk (i lighed med tysk) i mange tilfælde anvender fuge-e eller fuge-s til at binde de to elementer i et kompositum sammen.

Elementerne i et kompositum er ikke nødvendigvis simpleksord. Et eller begge elementer kan være komplekse ord dannet ved afledning. Endelig er der mulighed for flere omganges rekursivitet i dannelsen af komposita. Elementerne i et kompositum kan med andre ord selv være komposita, og disses elementer kan igen (i hvert fald principielt) være komposita, men et givet kompositum lader sig altid analysere $\mathrm{i}$ to og kun to elementer.

De semantiske relationer mellem elementerne i et kompositum kan være ganske mangeartede, og der er gjort mange fors $\emptyset \mathrm{g}$ på at udrede dem, som det vil føre for vidt at komme ind på her. Nedenfor er samlet en række eksempler på sammensætninger med gummi som første element, der viser lidt af mangfoldigheden.

Nogle danske komposita med gummi-

gummitra
gummimalk/-saft
gummiske
gummisko
gummiged
gummibamse
gummiansigt
gummicheck
gummiparagraf

Et gummitræ er et træ, hvoraf der udvindes gummi(saft), mens en gummiske er en ske der anvendes til opsamling af gummi(saft), og gummisko er sko lavet af gummi. En gummibamse har konsistens som gummi og form som en bamse, en gummiged har hjul af gummi, men ellers hverken 
meget med gummi eller ged at gøre. Et gummiansigt har noget af gummiens elasticitet, og det er også den egenskab, der i overført forstand kendetegner en gummicheck og en gummiparagraf.

På engelsk finder vi på tilsvarende måde sammensætninger med rubber som disse:

rubber plant, rubber planter, rubber band, rubber stamp (der anvendes både med betydningen gummistempel og om en nikkedukke eller en kliché), rubber cheque, rubber neck (om en nysgerrig turist), rubber face og rubber soul.

Dels forekommer der altså i sammensætninger med samme element forskellige typer af semantiske og (kvasi)syntaktiske relationer mellem elementerne, og dels indgår elementerne både med konkret og overført eller figurlig værdi. Analogislutninger kan derfor være farlige. Et møntvaskeri (eller en møntvask) er således ikke et sted hvor man kan få vasket sine mønter, selvom substantivkomposita hvor første element er objekt for det deverbale substantiv i andet element er meget almindelige, også med

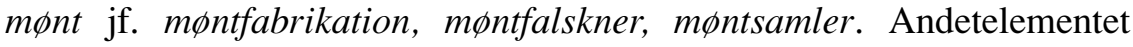
vask har også forskelligt indhold i forskellige sammensætninger, jf. $m \phi n t$ vask, bilvask, håndvask. Fejldiagnose anvendes undertiden i dagligsproget med samme betydning som fejlagtig diagnose 5 , men i givne fagsproglige sammenhæng også med betydning som diagnose af fejl. Sådanne eksempler understreger det banale men afgørende forhold, at en sammensætning (groft sagt) består af to ord der er sat sammen til et tredje ${ }^{6}$.

Vi forstår komposita som gummiske, gummiged, møntvask(eri), moderkage og sфsterkage, fordi vi kender verden og disse ords konventionelle referenceforhold til den. Det er med andre ord ud fra omstændighederne og vores viden om verden, at vi forstår, om en guldvægt er en vægt lavet af guld, en vægt der anvendes til vejning af guld eller den metaforiske vægt, nogle mennesker undertiden vejer deres ord på.

En anden tolkningsvanskelighed skyldes, at fagsproglige komposita kan vokse sig ganske lange. Derfor opstår der undertiden segmenteringsproblemer, når man møder ord som (eng.) large area ultra high density

5 Det er f. eks. den betydning, der ligger til grund for oversættelsesforslagene i H. Vinterberg og C. A. Bodelsen (1990) Dansk-engelsk Ordbog 3. udg. København: Gyldendal.

6 Jf. Laurie Bauer (1983) English Word-formation Cambridge: Cambridge U. P. (s. 11): 'compounding (or composition) is, roughly speaking, the process of putting two words together to form a third'.

7 På tysk, hvor lange komposita som Dauerarbeitslosigkeitsbekämpfungsplan ikke er ualmindelige, taler man om Bandwurmwörter. Jf. H. Bergenholz og J. Mugdan (1979) Einführung in die Morphologie Stuttgart: Kohlhammer (s. 175). 
interconnect systems eller (da.) flerkanalsbølgelangdemultipleksering7. Langdemultipleks eller kanalsbølge er ikke elementer i kompositummet. Det skal, som alle komposita, forstås som sammensat af to og kun to elementer, nemlig bølgelangdemultipleksering og flerkanal(s). At begge elementer selv er kompositumsformer indebærer ingen ændring $\mathrm{i}$ den fundamentale beskrivelse af, hvordan et kompositum er opbygget.

Segmenteringsproblemet bliver sjældent akut i den menneskelige kommunikation, men i forbindelse med nogle maskinoversættelsessystemers forsøg på at dekomponere ikke-leksikaliserede komposita er der fremkommet en del forn $\varnothing$ jelige forslag. ${ }^{8}$

\section{Klassifikation og oversættelse af komposita}

Den almindeligste klassifikation af komposita er efter, hvilken ordklasse de tilhører. På den måde får man en hovedgruppering i de kendte ordklasser: substantiver, verber, adjektiver, adverbier og partikler.

Mens der er udbredt enighed om hensigtsmæssigheden af den overordnede klassifikation, er der ingen konsensus om, hvordan en finere inddeling kan foretages. Substantivkomposita, der er langt de hyppigste, inddeles undertiden $\mathrm{i}$ fire undertyper: endocentriske, exocentriske, appositionelle og kopulative. Af disse er endocentriske dannelser, hvor kompositummet er hyponym til kompositummets andetelement suverænt den almindeligst forekommende. Andre typologier baserer sig på syntaktiske kriterier ${ }^{9}$, mens andre igen blander syntaktiske og semantiske kriterier10.

Når den overordnede indfaldsvinkel er oversættelse, er det afgørende imidlertid ikke, hvordan man bedst typologiserer komposita ud fra monolingvale eller universelle kriterier, men om det er muligt at foretage en kontrastiv typologisering, der kan tjene som hjælperedskab ved oversættelse af komposita, og her skuffes man.

Vinterberg og Bodelsen giver følgende ækvivalenter til nogle af de tidligere nævnte sammensætninger med gummi-:

\footnotetext{
8 Ifølge Frede Boje, Institut for tysk, HHK, foreslog systemet i Saarbrücken således sammensætningen Kulturinfiltration opløst i Kult-urin-filtration.

9 Således f. eks. Quirk et al. (1985) i A Comprehensive Grammar of the English Language London: Longman.

10 Valerie Adams (1973) An Introduction to Modern English Word-formation London: Longman, opstiller på det grundlag ikke mindre end 76 forskellige typer nominalkomposita, hvortil kommer en brokkasse med 'others'.
} 


$\begin{array}{ll}\text { gummitræ } & \text { rubber tree } \\ \text { gummimælk/-saft } & \text { rubber latex } \\ \text { gummisko } & \text { gym shoe (US sneaker) } \\ \text { gummiansigt } & \text { rubber face } \\ \text { gummiparagraf } & \text { (flexible clause) } \\ \text { gummicheck } & \text { rubber cheque } \\ \text { gummibamse } & \text { jelly baby } \\ \text { gummiged } & \text { loader tractor }\end{array}$

Det konstateres altså med det samme, at den omstændighed at dansk gummi meget stabilt ækvivalerer engelsk rubber, når de optræder alene, ikke indebærer, at vi kan være sikre på, at første led af et ækvivalent engelsk kompositum vil være rubber.

For at perspektivere den her skitserede problematik mere præcist i forhold til fagsprog er det nødvendigt at se nærmere på fagsproglig kompositering.

\section{Kompositering i fagsprog}

Kompositering er et af de mere iøjnefaldende træk ved det sprog fagfolk bruger, når de beskriver deres fagområde. Ofte er der her tale om ord der så at sige kun er kurante i den særlige faglige sammenhæng.

Naturligvis er der tale om glidende overgange og om overlapninger. Et fag som stemme- og sanglære opererer med en specifik fagterminologi, men en stor del af fagterminologien har faget til fælles med mere eller mindre nært beslægtede fag som fonetik, anatomi, retorik, musik, akustik og gymnastik. I Lone Rørbech \& Sten Høgels lille bog Tal rigtigt - syng godt (1984) forekommer således ord som alveolarrand, u-artikulation; svalgsnфrer, tudbrusk; stemmefфring, talestemme; legato, staccato; resonans, formant; afspaendingsøvelse og konditionstraning.

Andre ord anvendes såvel i fagsproglig sammenhæng som i det almindelige hverdagssprog. Når det gælder stemmelære er det fx. ord som brystkasse, mellemgulv, stemmelaber, strube, tungespids; også ord som tale, sang og snorkelyde. Undertiden kan der være anledning til at præcisere sådanne ords betydning i en given faglig sammenhæng, men ofte er en sådan præcisering ikke nødvendig.

Dette forhold, at der på den ene side er tale om fælles ordforråd med almensproget, og at der på den anden side er tale om overlappende anvendelse af fagord med andre fag, er typisk for de fleste fagsprog, når fagsprog defineres som det sprog fagfolk anvender, når de kommunikerer om deres fagområde. 
Berøringen mellem fagsprogene indbyrdes og mellem fagsprog og vores almindelige hverdagssprog giver os mulighed for at forstå hinanden, et stykke af vejen. Men ofte netop kun et stykke af vejen. For med mindre man netop er fortrolig med fagområdet og det dertil hørende fagsprog løber man hurtigt ind i vanskeligheder, af tre slags:

Dels er der de helt fagspecifikke ord, som (næsten) kun anvendes af fagfolk inden for det særlige område. I tilfældet stemmelære er det ord som blandingsoktav, kortregister, staccatokoloratur og vokalegalisering.

Dels kender man sjældent til alle de fagord, fagområdet har til fælles med andre fagområder (jf. de allerede citerede ord), og de eventuelle særlige betydninger disse ord anvendes med i den givne faglige sammenhæng.

Og endelig giver det problemer for ikke-fagmanden, at fagsprog typisk anvender mange komposita, hvis betydning tilsyneladende, men netop kun tilsyneladende lader sig konstruere på baggrund af almensproglig viden.

De fire just nævnte ord blandingsoktav, kortregister, staccatokoloratur og vokalegalisering er alle kompositerede former, men af en type, som de fleste ikke-fagfolk formodentlig ville opgive at tyde, fordi de næppe ville være fortrolige med mere end det ene af leddene i sammensætningerne. Derimod ser ord som højdeleje, hviskeridsen, registerknak, stemmegivning, stemmestilling umiddelbart tilgængelige ud, hvad de bare ikke er, fordi de som det er almindeligt, er kompositumsformer bestående af almensproglige elementer, der sammensat anvendes med et veldefineret fagspecifikt indhold, som ikke kan infereres ud fra de kendte almensproglige betydningskomponenter.

Når det altså gælder om at inferere en specifik fagsproglig betydning af et kompositum, der tilsyneladende består af fuldt transparente konstituenter, er man på temmelig bar bund. Højdeleje kan formodentlig ikke være hvadsomhelst, men på den anden side kan det med det væld af mulige aktualiserede konstituentbetydninger og deres indbyrdes syntaktisk/semantiske relationer være så meget, at man ingen mulighed har for at komme med et sandsynligt bud på kompositummets betydning 11 .

Det må altså konstateres, at det ikke er muligt med en rimelig grad af sandsynlighed at inferere den nøjere betydning af et ikke-bekendt

11 Ordet anvendes faktisk i to forskellige betydninger i bogen, hvad der heller ikke er til at forudse, medmindre man besidder fagviden. 
fagsprogligt kompositum, selv hvor det består af tilsyneladende transparente og kendte konstituenter. Derfor er vi alle afhængige af hjælp til forståelse af fagtekster, der ligger uden for vort eget fagekspertområde.

Oversætteren, der sjældent selv er fagekspert, har det yderligere problem, at forståelsen af kildeteksten kun er begyndelsen. Når betydningsindholdet af et fagsprogligt kompositum er forstået, melder spørgsmålet om oversættelsesækvivalenterne sig. Som det allerede er antydet, er de mindst lige så vidensafhængige som tolkningen af komposita. Ofte ækvivalerer et dansk kompositum med et engelsk (og omvendt), men ofte er ækvivalenten et simpleksord (stemmeh $\phi j d e ~::$ pitch) eller en fri frase (alveolarrand $\because$ alveolar ridge). Dette forhold aktualiserer spørgsmålet om omfanget af oversættelsesordbøgernes behandling af komposita.

\section{Eksemplificering af den leksikografiske dækning af komposita.}

(Eksempler fra Lone Rørbech \& Sten Høgel: Tal rigtigt - syng godt, København, 1984.)

Som illustration på hvor godt eksisterende da/eng ordbøger dækker fagsproglige komposita kan vi undersøge to meget hyppigt forekommende sammensætninger (i bogen), nemlig sammensætninger med register og stemme:

Ser vi først på sammensætninger med -stemme, er resultatet følgende, næsten ideelle situation:

$\begin{array}{lll}\begin{array}{ll}\text { stemme: } \\ \text { kvindestemme }\end{array} & \text { VB3 } & \text { DEU12 } \\ & \begin{array}{l}\text { female voice } \\ \text { woman's voice }\end{array} & \begin{array}{l}\text { female voice } \\ \text { woman's voice }\end{array} \\ \text { mandsstemme } & \text { male voice } & \text { male voice } \\ & \text { man's voice } & \text { man's voice } \\ \text { mellemstemme } & \text { mus: (ml. sopran og alt) } & \varnothing \\ & \text { mezzosoprano; (ml. } & \\ \text { tenor og bas) baritone; } & \\ \text { (i kor) inner part } & \\ \text { menneskestemme } & \text { human voice } & \text { human voice } \\ \text { sangstemme } & \text { singing voice } & \text { singing voice } \\ \text { talestemme } & \text { speaking voice } & \varnothing\end{array}$

Der er kun tale om en næsten ideel situation, fordi det kan diskuteres, om det er rimeligt at selektere sangstemme frem for talestemme i DEU, og

12 VB3: H. Vinterberg og C. A. Bodelsen (1990) Dansk-engelsk Ordbog

DEU: J. Axelsen (1990) Dansk-engelsk Ordbog. Undervisning København: Gyldendal. 
fordi ingen af de i VB3 anførte oversættelsesækvivalenter dækker den (i den givne sammenhæng) relevante betydning af mellemstemme.

Men ovenstående er på ingen måde typisk. Selektionen af fagudtryk er oftest meget ufuldstændig selv i store ordbøger. Den typiske situation kan illustreres ved sammensætninger med -brusk:

$\begin{array}{lll}\text { brusk } & \mathbf{V B 3} & \text { DEU } \\ \text { ringbrusk } & \text { cricoid cartilage } & \varnothing \\ \text { skjoldbrusk } & \text { thyroid cartilage } & \text { thyroid cartilage } \\ \text { strubebrusk } & \varnothing & \varnothing \\ \text { tudbrusk } & \text { arytenoid cartilage } & \varnothing \\ \text { tudbruskmuskler } & \varnothing & \varnothing\end{array}$

Det sidst anførte eksempel illustrerer det forhold, at den leksikalske dækning tynder ud, jo længere en sammensætning bliver. I bogen skelnes fx. mellem forreste ringbrusk- tudbruskmuskler og bageste ringbrusktudbruskmuskler, og der tales også om skjoldbrusk- tudbruskmuskler. Ingen af disse forekommer i ordbøgerne.

Inden konsekvenserne af denne mangelfulde leksikalske inddækning diskuteres, kan yderligere eksempler anføres.

\section{Sammensætninger med register- og -register ${ }^{13}$.}

Både VB3 og DEU medtager register alene og oplyser korrekt, at det tilsvarende engelske ord er register, men ingen af ordbøgerne medtager en eneste af nedenstående sammensætninger, som spiller en meget afgørende rolle for formidlingen af indholdet:

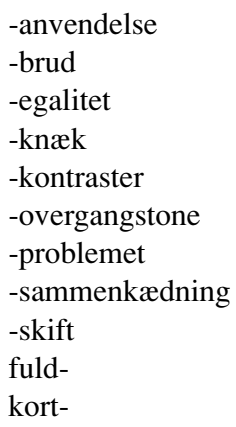

13 Der ses bort fra sagregister, der ganske vist forekommer i teksten, men ikke er en del af det fagspecifikke sprog. 
lav-

rand-

mellem-

rand-

stemme-

Endvidere forekommer:

fuldregisterfunktion, fuldregistersang, fuldregistertone randregisterfunktion, randregistersvingning

Spørgsmålet er, hvordan man mest hensigtsmæssigt gør det muligt at oversætte sådanne ord for dem, der ikke har sproglige ækvivalenter som en del af deres vidensberedskab.

Som situationen er, er en sådan oversætter henvist til enten at søge viden (fx. fra paralleltekster) om, hvordan ækvivalente begreber formuleres på det fremmede sprog, eller (hvis dette ikke er muligt) til at parafrasere den infererede/formodede betydning eller at konstruere en målsprogsform ved analogidannelse. Har man fx. middle voice register, tror man sig måske tilstrækkeligt sikker til at forsøge sig med high voice register og low voice register, hvad der givetvis ville blive forstået, selv om det ikke er i overensstemmelse med indfødte fageksperters sprogbrug.

\section{Sammensætninger med stemme.}

Sammensætningerne med stemme giver et endnu fyldigere billede af problematikken:

VB3 har her en meget omfattende dækning. Der er medtaget ikke mindre end 22 komposita med stemme- (i den relevante betydning). Tror man sig imidlertid godt hjulpet til at oversætte Tal rigtigt - syng godt, kommer man på bedre tanker.

Nedenstående sammensætninger med stemme- med tilhørende (første) ækvivaleringsforslag forekommer i VB3:

-apparat
-begavet
-brug
-bånd
-båndskatar
-båndslukke
-dannelse
-frembringelse
-fylde
-føring
-højde

vocal apparatus have a good voice use of the voice vocal $\mathrm{c}(\mathrm{h})$ ord laryngitis closure of the vocal chords voice production voice production volume of voice voice pitch 


$\begin{array}{ll}\begin{array}{ll}\text {-klang } \\ \text {-kunst }\end{array} & \begin{array}{l}\text { timbre } \\ \text { vocal art } \\ \text {-leje }\end{array} \\ \text {-læbe } & \text { (vocal) pitch } \\ \text {-lægning } & \text {-bånd } \\ \text {-omfang } & \text { voice production } \\ \text {-placering } & \text { compass } \\ \text {-pleje } & \text { placing of the voice } \\ \text {-ridse } & \text { the care of the voice } \\ \text {-skønhed } & \text { glottis } \\ \text {-tab } & \text { beauty of voice } \\ & \text { loss of the voice }\end{array}$

I den lille stemmelærebog forekommer nogle af disse, men endvidere:

-ansats
-arbejde
-brugslære
-dannelsesarbejde
-dynamik
-forstyrrelse
-funktion
-fysiologisk (adj.)
-givning
-gruppe
-hvile
-instrument
-kategori
-knæk
-kompression
-lig (adj.)
-lukke
-læbefunktion
-læbekompression
-læbelukke
-læbemodstand

-læbemuskel
-læbespænding
-misbrug
-muskler
-organ
-register
-stilling
-styrke
-svigt
-tap
-teknik
-teoretisk
-tone
-træning
-træthed
-typer
-uddannelse
-udfoldelse
-øvelse
-øvelsesarbejdet

Oversætteren mangler i det givne tilfælde med andre ord 41 oversættelsesækvivalenter, vel at mærke på et område, hvor ordbogens dækning er væsentligt mere omfattende end gennemsnitligt.

Det er indlysende, at ordbogens oversættelsesækvivalenter ikke har tilstrækkelig ensartethed til at give baggrund for sikre analogislutninger. Hertil kommer naturligvis den omstændighed, at oversætteren ikke altid trygt kan forlade sig på, at ordbogens oversættelsesforslag holder i den givne sammenhæng. Ordbogen sætter fx. lighedstegn mellem stemmelabe og stemmebånd. Den fagligt anvendte betegnelse svarende til stemmelabe er imidlertid vocal fold, hvad man ikke finder i VB3. For stemmedannelse er anført voice production, men i stemmelæren bruges en 
anden betydning af stemmedannelse, der svarer til voice building eller voice formation, mens voice production ofte svarer til stemmegivning ${ }^{14}$.

\section{Konklusion}

Sammenfattende kan det konstateres, at det ikke generelt er muligt at konstruere ækvivalenter til komposita ved hjælp af strategier baseret på dekomposition og kompostition. Ligeledes må det konstateres, at analogislutninger ikke generelt kan anvendes til konstruktion af ækvivalenter. Parafrase, en ækvivaleringsstrategi der ikke er diskuteret, er mindre interessant, fordi en måltekst der fremkommer som resultat af denne ækvivaleringsstrategi mister faglighedspræg.

En oversætter, der har hjælp behov, men ikke får den af ordbogen, er derfor henvist til at kende og beherske og ellers at læse/lære om faget (stemmelære) på målsproget for at kunne oversætte. Faget skal som minimum beherskes så godt, at oversætteren véd, hvad der er hvad, både i den kildesproglige fagbeskrivelse, og i målsprogets. Oversætteren må altså sætte sig ned og læse om phonation (vocal fold vibration), mode of phonation, normal/modal phonation, phonation characteristics, adduction of the vocal folds, abduction of the vocal folds, tensioning of the vocal folds, tension in the vocal folds, vocal fold tension osv. osv., og således ved egen indsats finde de relevante oversættelser, der netop skal kendes eller findes, fordi de ikke lader sig konstruere ved hjælp af regler.

Her ligger en opgave for tosprogsleksikografien, som må påtage sig at redegøre langt mere udførligt end hidtil for ækvivaleringsmulighederne til komposita. Sammensatte ord er ganske vist sammensatte, men først og fremmest er de ord, og hører derfor hjemme i gode ordbøger.

\footnotetext{
14 I parentes kan det nævnes at stemmegivning forekommer i VB3, men som homograf til den her relevante. (VB3 har: stemmegivning $=$ stemmeafgivning voting).
} 